\title{
РАЗРАБОТКА СТРАТЕГИИ ФАРМАКОЛОГИЧЕСКОЙ КОРРЕКЦИИ ОТКЛОНЕНИЙ У ПОТОМСТВА С ОСЛОЖНЕННЫМ РАННИМ ОНТОГЕНЕЗОМ
}

\author{
Е.А. Музыко, В.Н. Перфилова, И.Н. Тюренков \\ Кафедра фармакологии и фармации Института НМФО, ВолгГМУ, \\ 400131, Россия, Волгоград, площадь Павших Борцов, д.1.
}

DOI: 10.19163/MedChemRussia2021-2021-331

E-mail: muzyko.elena@mail.ru

Преэклампсия - патологическое состояние, возникающее во время беременности и характеризующееся повышенным риском формирования заболеваний нервной, сердечно-сосудистой, эндокринной и других систем у потомства на разных этапах жизни [1]. В этой связи разработка средств и способов предупреждения и лечения подобных осложнений является актуальной. Перспективными соединениями являются производные ГАМК, обладающие ноотропным, нейро- и эндотелиопротекторным, антигипоксическим и антиок-сидантным эффектами [2, 3]. В ходе эксперимента потомству крыс с экспериментальной преэклампсией (ЭП), смоделированной заменой питьевой воды на 1,8% p-p NaCl с 1 по 21 день гестации [3], с 40 по 70 день и с 24 по 25 месяц жизни внутрижелудочно вводили производные ГАМК сукцикард (22 и 44 мг/кг), салифен (7,5 и 15 мг/кг), фенибут (25 и 50 мг/кг) и препарат сравнения пантогам (50 и 100 мг/день). У животных в возрасте 3, 6, 12, 18 и 25 месяцев изучали кратковременную рабочую память в тесте «Распознавание нового объекта» и рассчитывали коэффициент дискриминации (Кд). Его увеличение расценивали как улучшение когнитивных процессов.

У самцов и самок разного возраста от крыс с осложненной беременностью отмечались нарушения памяти, что выражалось в более низком, чем у потомства здоровых крыс, Кд. Сукцикард, салифен, фенибут и пантогам оказывали благоприятной действие на рабочую память животных в 3, 6, 12 месяцев. Однако к 18 месяцам эффект от терапии в пубертатном периоде начал ослабевать и высокую активность сохранял только сукцикард. При поздней фармакотерапии Кд был значительно больше у животных, которым вводили сукцикард, салифен и пантогам, по сравнению с группой негативного контроля. Таким образом, можно сделать вывод о том, что среди изучаемых производных ГАМК сукцикард является одним из наиболее перспективных веществ для коррекции нарушений кратковременной рабочей памяти у потомства, рожденного матерями с осложненной беременностью, как на ранних, так и на поздних этапах постнатального онтогенеза.

\section{Литература}

[1] Lu, H.Q., Hu, R., AJP Rep. 2019, 9(3):e275-e291. doi: 10.1055/s-0039-1695004.

[2] Бурчинский, С.Г. Междунар. невролог.журнал. 2015, 1 (71): 101-105.

[3] Tyurenkov, I.N., Perflova, V.N., Popova, T.A. [et al.]. Bull Exp Biol Med. 2013, 155(3):363-5. doi: 10.1007/s10517-013-2154-9. 